\title{
DYNAMIC LINKAGES BETWEEN STOCK MARKETS: EVIDENCE FROM USA, GERMANY, CHINA AND RUSSIA

\author{
Rogneda Vasilyeva ${ }^{1}$, Valentin Voytenkov ${ }^{2}$, Alina Urazbaeva ${ }^{3}$
}

\begin{abstract}
Currently, financial markets are growing rapidly, which increases the necessity to examine the financial sector. Considering the Russian Federation, the amount of private investors has doubled in Russia since the beginning of 2020 (Finam, 2020). It is important to realize how cash flows between the largest stock market indices. The main hypothesis of the research suggests that the U.S., Germany, and China markets result in significant changes in the Russian stock market. The research objective is to determine the degree of the Russian stock market dependence on the markets of developed and developing countries using methods of econometric analysis. Daily data on S\&P500, DAX30, Hang Seng, and Moscow Exchange Index from January 1, 2015, to December 31, 2019, were taken. The research method chosen is a cointegration approach, including the construction of vector autoregression and vector error-correction models and the application of Impulse Response Functions. The results of the Granger causality test reveal no significant interconnection between the Dax30 and the Moscow Stock Exchange Index; the S\&P500 affects the Moscow Exchange Index, whereas the Russian stock market affects the Chinese one. According to the cointegration analysis, there is a strong positive influence of the American stock market on the Russian stock market, which does not decrease during the researched period. The stock indices of China and Germany show a weak quantitative influence and mixed dynamics for a long time. The results of the research could be used as recommendations for making management decisions by private investors, hedge funds and managers of large companies.
\end{abstract}

JEL Classification Numbers: C32, C58, G15, DOI: https://doi.org/10.12955/peb.v2.260

Keywords: stock markets, Moscow exchange index, cointegration analysis, volatility, Impulse Response Functions.

\section{Introduction}

The first exchange in the world was founded in 1602, since then, various approaches to asset value analysis had been implemented (Tenshin, 2019). Currently, the most common types of analysis are technical and fundamental. The technical approach stands for forecasting future price changes based on the analysis of price changes in the past (Linkova, 2016). The fundamental approach implies predicting changes in asset prices by using the macroeconomic analysis and comparing the performance of a company with the industry median (Khromov, 2010). The econometric analysis is used to evaluate financial assets and predict their value using econometric modelling (Fantazzini \& Dean, 2008). The increased interest of individuals in the analysis of financial time series makes it more and more relevant. For instance, the number of individual investors in Russia doubled in 2020: from 3.6 million people in January to 7.5 million in October (Finam, 2020). This fact brings special relevance to the topic of this study, namely the interaction of the largest financial markets in the world, which are the United States of America, China, Germany, and the Russian Federation.

The most common econometric methods applied to the analysis and forecast of financial time series are the vector autoregression (VAR) (Taveeapiradeecharoen et al., 2019) and the global vector autoregression (GVAR) modelling (Pesaran et al., 2009), the vector error correction model (VECM) (Kularatne, 2002), autoregressive moving average (ARMA) (Taylor, 2007), autoregressive integrated moving average (ARIMA) (Alwadi et al., 2011), generalized autoregressive conditional heteroskedasticity (GARCH) (Lin, 2018), autoregressive distributed lag (ARDL) (Shrestha \& Chowdhury, 2005).

\section{Literature background}

G. Dhesi and L. Xiao (2010) tested the hypothesis that the American financial market affects the markets of Germany, France, and the United Kingdom. They found out that the significant changes in the U.S. stock market lead to increased volatility on Asian exchanges. At the same time, there is an asymmetry of volatility. Changes in the UK market lead to considerable changes in the European markets (France, Germany, Italy); however, significant fluctuations in the S\&P500 index affect both British and American indices (Don Jones, NASDAQ).

\footnotetext{
${ }^{1}$ Graduate School of Economics and Management, Ural Federal University, Ekaterinburg, Russian Federation, ronav999@gmail.com

${ }^{2}$ Graduate School of Economics and Management, Ural Federal University, Ekaterinburg, Russian Federation, voivall@yandex.ru

${ }^{3}$ Graduate School of Economics and Management, Ural Federal University, Ekaterinburg, Russian Federation, alina.urazbaeva2000@gmail.com
} 
P. Mukherjee and S. Bose (2008) confirmed that U.S. indices have a slight impact on the entire Asian market. Conversely, the Japanese market significantly affects all Asian and American indices.

H. Berumen and O. Ince (2005) found out that the S\&P500 index affects the ISE100, the largest stock index of Turkey. They also concluded that the correlation coefficient with the U.S. depends on the geographical location of the stock markets.

Contrarily, several studies refuse the linkages between the markets. A. Kanas (1998) established that the U.S. stock market and the markets of Great Britain, Germany, France, Switzerland, Italy, and the Netherlands were not co-integrated in pairs, which meant that there were no long-term links between the U.S. and any of the main European markets.

E. Fedorova (2013) found no correlation between the RTS (Russia) and DAX30 (Germany), RTS, and S\&P500 (the U.S.) indices. The connection was detected between the RTS and Golden Dragon (China). The influence of the VIX fear index on the RTS was also observed. During the crisis period, the situation on the markets does not change co-integration vectors only in the pair of RTS and Golden Dragon.

D. Samoylov (2010) revealed a multidirectional impact of the FTSE and S\&P 500 indices on the Russian stock market during the pre-crisis and post-crisis periods. The RTS directly depends on the S\&P 500, FTSE, and VIX indices in pre-crisis periods, which, in their turn, depend on oil futures. The crisis period is characterized by a decline in the influence of S\&P 500 and FTSE indices, but the impact of oil prices and the VIX fear index remains. The price of oil and the S\&P500 keep being the main guides of the RTS index in the post-crisis period.

The study by E. Fedorova and Y. Nazarova (2010) highlights the factors that can cause volatility and frequent changes in the RTS index: the Brazilian stock market index (BOVESPA), the German stock market index (DAX), world oil prices (Brent), and world gold prices (London Fix PM, Gold). They also reveal that one of the factors influencing the volatility of the Russian stock market is the S\&P500.

The analytical note on the growth drivers of the MICEX index (Karpov, 2017) confirms that the Russian market is influenced by indices of both developed and developing markets.

Most researchers consider only the largest financial markets. Therefore, there is a lack of analysis of the interrelation between developing and developed financial markets in the existing literature. This research aims to explore this issue and provide a complete and relevant assessment of the situation in the financial markets of the U.S., Germany, China, and Russia. The result of this research can be useful to investors and financial institutions engaged in long-term investing in international markets.

\section{Data and methodology}

Based on the literature review, the S\&P500 Index (USA), Hang Seng Index (China), DAX 30 Index (Germany) were selected as factors affecting the Moscow Exchange index (MOEX). The dataset contains daily data from January 1, 2015, until December 31, 2019. The time series were transformed into logarithmic series and located within a single range; 1156 observations are available for each series. The descriptive statistics for the dataset are provided in Table 1.

Table 1: Descriptive statistics for variables

\begin{tabular}{|l|l|l|l|l|}
\hline & MOEX & S\&P500 & Hang Seng & Dax 30 \\
\hline Mean & 2130.36 & 2454.00 & 25697.11 & 11601.79 \\
\hline Median & 2071.48 & 2435.86 & 26036.11 & 11755.90 \\
\hline Maximum & 3033.81 & 3239.91 & 33154.12 & 13559.60 \\
\hline Minimum & 1435.66 & 1829.08 & 18319.58 & 8879.40 \\
\hline Std. Dev. & 362.70 & 358.11 & 3208.80 & 1064.58 \\
\hline Skewness & 0.47 & 0.17 & -0.12 & -0.35 \\
\hline Kurtosis & 2.40 & 1.68 & 2.21 & 2.13 \\
\hline Jarque-Bera & 60.31 & 89.48 & 32.70 & 60.24 \\
\hline Probability & 0.00 & 0.00 & 0.00 & 0.00 \\
\hline Sum & 2462691 & 2836830 & 29705857 & 13411670 \\
\hline Sum Sq. Dev. & 152000000 & 148000000 & 11900000000 & 1310000000 \\
\hline Observations & 1156 & 1156 & 1156 & 1156 \\
\hline Source: Authors & & & \\
\hline
\end{tabular}


The P-value of the Jarque-Bera statistic is close to 0, which suggests that the errors of each time series do not have a normal distribution. In this sample, the distribution is flat-topped for all the series. Rightsided asymmetry is present for the MOEX index and the S\&P500 and left-sided for the Dax30 and Hang Seng indices.

In order to work with the value of assets in the stock market (stocks, commodities, etc.), it is necessary to bring them to the form of white noise, which is a stationary process with constant mathematical expectation, constant variance, and a zero autocovariance function for all but zero lag. It is achieved by taking the logarithm of the growth rate number (equation 1) (Sarwar et al., 2020; Urazbaeva et al., 2020).

$$
r=\ln \left(\frac{P_{t}}{P_{t-1}} * 100 \%-100 \%\right)
$$

where $r$ is the return to the previous period for time $(t=1,2, \ldots, T)$, and $P_{t}$ presents the growth rate number of particular indices at time.

\section{Results and discussion}

To determine the order of integration (the stationarity of the series), the Dickey-Fuller test (DF-test) was implemented. The results of the test are presented in Table 2.

\begin{tabular}{|l|l|l|l|}
\hline Table 2: Results of DF-test \\
\begin{tabular}{|l|l|l|l|}
\hline \multicolumn{1}{|c|}{ Intercept with trend } & \multirow{2}{*}{ Output } \\
\hline Variable name & Level & First difference & I=1 \\
\hline DAX30 & -2.31 & $-33.22^{* * *}$ & $\mathrm{I}=1$ \\
\hline Hang Seng & -1.48 & $-32.50^{* * *}$ & $\mathrm{I}=1$ \\
\hline MOEX & -1.13 & $-33.27^{* * *}$ & $\mathrm{I}=1$ \\
\hline S\&P & -0.47 & $-34.79^{* * *}$ & \multicolumn{2}{l|}{} \\
\hline
\end{tabular}
\end{tabular}

Levels of significance: $* * * p<0,01, * * p<0,05, * p<0,10$

Source: Authors

Considering the integration order equal to $0(\mathrm{I}=0)$, none of the original series is stationary. However, the series became stationary after taking the first differences, which confirms that integration order equals $1(\mathrm{I}=1)$. It allows us to apply the cointegration analysis by the Johansen approach.

Since the Johansen approach is sensitive to the choice of lags in the model, it is necessary to select the optimal number of lags. The set of criteria for lag selection is presented in Table 3, where LR is Likelihood ratio, Final Prediction Error (FPE), Hannan-Quinn Criterion (HQ), Akaike's Information Criterion (AIC), Schwarz Criterion (SC).

\begin{tabular}{|l}
\hline Table 3: Results of lag length criteria test \\
\begin{tabular}{|l|l|l|l|l|l|}
\hline Lag & LR & FPE & AIC & SC & HQ \\
\hline $\mathbf{0}$ & NA & $7.2 \mathrm{e}-10$ & -9.70 & -9.68 & -9.69 \\
\hline $\mathbf{1}$ & 17976.42 & $1.1 \mathrm{e}-16$ & -25.40 & -25.31 & -25.36 \\
\hline $\mathbf{2}$ & 473.99 & $7.4 \mathrm{e}-17$ & -25.79 & -25.63 & -25.73 \\
\hline $\mathbf{3}$ & 176.67 & $6.6 \mathrm{e}-17$ & -25.91 & $-25.68^{*}$ & -25.83 \\
\hline $\mathbf{4}$ & $66.49^{*}$ & $6.4 \mathrm{e}-17^{*}$ & $-25.94^{*}$ & -25.64 & $-25.83^{*}$ \\
\hline
\end{tabular}
\end{tabular}

* indicates lag significance

Source: Authors

Table 4: Results of Johansen test

\begin{tabular}{|l|l|l|l|l|l|l|l|}
\hline Model 1 & Model 2 & Tax-Eig \\
\hline Data trend & Test type & Trace & Max-Eig & Data trend & Test type & Trace & Max-e \\
\hline None & $\begin{array}{l}\text { No intercept, } \\
\text { no trend }\end{array}$ & 0 & 0 & None & $\begin{array}{l}\text { No intercept, } \\
\text { no trend }\end{array}$ & 0 & 0 \\
\hline None & $\begin{array}{l}\text { Intercept, no } \\
\text { trend }\end{array}$ & 1 & 1 & None & $\begin{array}{l}\text { Intercept, no } \\
\text { trend }\end{array}$ & 0 & 1 \\
\hline Linear & $\begin{array}{l}\text { Intercept, no } \\
\text { trend }\end{array}$ & 1 & 1 & Linear & $\begin{array}{l}\text { Intercept, no } \\
\text { trend }\end{array}$ & 0 & 1 \\
\hline Linear & $\begin{array}{l}\text { Intercept, } \\
\text { trend }\end{array}$ & 1 & 1 & Linear & $\begin{array}{l}\text { Intercept, } \\
\text { trend }\end{array}$ & 1 & 0 \\
\hline Quadratic & $\begin{array}{l}\text { Intercept, } \\
\text { trend }\end{array}$ & 1 & 1 & Quadratic & $\begin{array}{l}\text { Intercept, } \\
\text { trend }\end{array}$ & 2 & 0 \\
\hline
\end{tabular}

Source: Authors 
According to Table 3, four out of five criteria show the significance of the fourth lag. The Schwarz criterion reveals the significance of the fifth lag. The models are sensitive to the ordinal number of lags, so two models will be considered for objective analysis. Model 1 is the model with 4 lags. This model is preferred due to lag significance in the most of information criteria. Model 2 includes three lags, respectively. The result of the Johansen cointegration test is in Table 4.

This test determines the presence of paired cointegration, which indicates a long-term relationship between the studied time series. Based on the results of the test, a vector error correction model (VECM) was built for model 1 and vector autoregression (VAR) for model 2 due to the lack of cointegration. The simulation results for model 1 are presented in Table 5.

\begin{tabular}{|l|l|l|l|l|l|l|l|l|}
\hline Table 5: Results of cointegration equation \\
\hline Variable & Coefficient & $\begin{array}{l}\text { Standard } \\
\text { errors }\end{array}$ & $\begin{array}{l}\mathbf{t}- \\
\text { statistics }\end{array}$ & $\begin{array}{l}\text { Critical } \\
\text { value of t } \\
\text {-statistics } \\
\text { on 1\% } \\
\text { level }\end{array}$ & $\begin{array}{l}\text { Critical } \\
\text { value of t } \\
\text {-statistics } \\
\text { on 5\% } \\
\text { level }\end{array}$ & $\begin{array}{l}\text { Critical } \\
\text { value of t } \\
\text {-statistics } \\
\text { on 10\% } \\
\text { level }\end{array}$ & Output \\
\hline MOEX & 1.00 & - & - & 2.58 & 1.96 & 1.64 & \\
\hline Dax30 & 0.81 & 0.18 & 4.52 & 2.58 & 1.96 & 1.64 & $\begin{array}{l}\text { significant } \\
\text { at 1\% level }\end{array}$ \\
\hline S\&P & -1.57 & 0.10 & -16.11 & 2.58 & 1.96 & 1.64 & $\begin{array}{l}\text { significant } \\
\text { at 1\% level }\end{array}$ \\
\hline $\begin{array}{l}\text { Hang- } \\
\text { Seng }\end{array}$ & 0.23 & 0.13 & 1.78 & 2.58 & 1.96 & 1.64 & $\begin{array}{l}\text { significant } \\
\text { at 10\% } \\
\text { level }\end{array}$ \\
\hline Constant & -5.38 & - & - & & & & & \\
\hline
\end{tabular}

Source: Authors

The coefficients for Dax30, S\&P500 are significant at the 1\% level, and the Chinese stock index HangSeng is significant at the $10 \%$ level.

The Granger causality test is performed to establish causal relationships between time series in the short term. The results of the Granger test for models 1 and 2 are presented in Table 6.

\begin{tabular}{|c|c|c|c|c|c|c|c|}
\hline \multicolumn{4}{|l|}{\begin{tabular}{|l|} 
Model 1 \\
\end{tabular}} & \multicolumn{4}{|l|}{ Model 2} \\
\hline \multirow[t]{2}{*}{ Variable } & \multicolumn{2}{|c|}{$\begin{array}{l}\text { Probability value } \\
\text { for the hypothesis }\end{array}$} & \multirow[t]{2}{*}{$\begin{array}{l}\text { Interpretation } \\
\text { (short-run) }\end{array}$} & \multirow[t]{2}{*}{ Variable } & \multicolumn{2}{|c|}{$\begin{array}{l}\text { Probability value } \\
\text { for the hypothesis }\end{array}$} & \multirow[t]{2}{*}{$\begin{array}{l}\text { Interpretation } \\
\text { (short-run) }\end{array}$} \\
\hline & $\begin{array}{l}\text { MOEX } \\
\text { does not } \\
\text { Granger } \\
\text { Cause } \\
\text { Variable }\end{array}$ & $\begin{array}{l}\text { Variable } \\
\text { does not } \\
\text { Granger } \\
\text { Cause } \\
\text { MOEX }\end{array}$ & & & $\begin{array}{l}\text { MOEX } \\
\text { does not } \\
\text { Granger } \\
\text { Cause } \\
\text { Variable }\end{array}$ & $\begin{array}{l}\text { Variable } \\
\text { does not } \\
\text { Granger } \\
\text { Cause } \\
\text { MOEX }\end{array}$ & \\
\hline Dax30 & 0.39 & 0.17 & $\begin{array}{l}\text { No } \\
\text { relationships }\end{array}$ & Dax30 & 0.24 & 0.002 & $\begin{array}{l}\text { MOEX <= } \\
\text { Dax30 }\end{array}$ \\
\hline S\&P500 & 0.85 & 0.00 & $\begin{array}{l}\text { MOEX <= } \\
\text { S\&P500 }\end{array}$ & S\&P500 & 0.13 & 0.00 & $\begin{array}{l}\text { MOEX <= } \\
\text { S\&P500 }\end{array}$ \\
\hline $\begin{array}{l}\text { Hang } \\
\text { Seng }\end{array}$ & 0.004 & 0.48 & $\begin{array}{l}\text { MOEX => } \\
\text { Hang - Seng }\end{array}$ & $\begin{array}{l}\text { Hang } \\
\text { Seng }\end{array}$ & 0.00 & 0.15 & $\begin{array}{l}\text { MOEX => } \\
\text { Hang - Seng }\end{array}$ \\
\hline
\end{tabular}

Source: Authors

The models depicted different results. Model 1 revealed that only the S\&P500 affects the MOEX index in the short term. No short-term relationship was found between MOEX and DAX30. The Russian market affects the Chinese market through the Hang-Seng index. These results are confirmed by the analytical note by Mikhail Zeltser, BCS expert (2020). This sample does not contain large macroeconomic shocks, so the influence of the S\&P500 in the model is considerable. Model 2 confirmed that the MOEX index is influenced by the S\&P 500 and Dax 30. The MOEX index is the reason for the change in the Chinese Hang-Seng index.

The robustness of the models was checked by applying the LM test (Table 7) for the presence of autocorrelation of the first and higher orders. Autocorrelation violates the condition of the GaussMarkov assumptions that the disturbances are uncorrelated at different times (Demidova, 2020). 
Table 7: Results of the autocorrelation test for both models

\begin{tabular}{|l|l|l|l|l|}
\hline & Model 1 & Model 2 & \multicolumn{1}{l|}{} \\
\hline Lags & LM-Stat & Prob & LM-Stat & Prob \\
\hline $\mathbf{1}$ & 10.92 & 0.81 & 88.00 & 0.00 \\
\hline $\mathbf{2}$ & 15.99 & 0.45 & 77.28 & 0.00 \\
\hline $\mathbf{3}$ & 10.29 & 0.85 & 57.95 & 0.00 \\
\hline $\mathbf{4}$ & 13.50 & 0.64 & 24.33 & 0.08 \\
\hline $\mathbf{5}$ & 11.36 & 0.79 & 14.57 & 0.56 \\
\hline $\mathbf{6}$ & 11.18 & 0.80 & 17.82 & 0.33 \\
\hline $\mathbf{7}$ & 23.97 & 0.09 & 23.72 & 0.10 \\
\hline $\mathbf{8}$ & 24.44 & 0.08 & 27.22 & 0.04 \\
\hline
\end{tabular}

Source: Authors

For the first model, there is no autocorrelation at all lags. For the second model, there is autocorrelation at the first three lags. It means that more robust and predictable results are presented by the first model. Heteroscedasticity also was considered when checking the robustness. The results of the White test for heteroscedasticity are presented in Table 8 . The heteroscedasticity is present in both models.

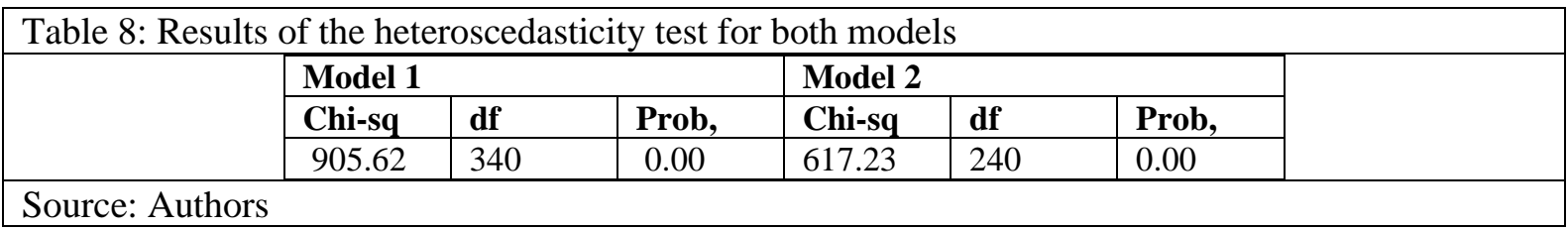

Two models were compared to construct quantitative estimates of the coefficients for the model (impulse response functions). The comparison results are in Table 9.

\begin{tabular}{|}
\hline \multicolumn{2}{|l|}{ Table 9: Comparison of two models } \\
\begin{tabular}{|l|l|l|l|}
\hline Model 1 & Model 2 \\
\hline Comparison criterion & Conclusion & Comparison criterion & Conclusion \\
\hline Lag length criteria & 4-th lag & Lag length criteria & 3-th lag \\
\hline Cointegration & $\begin{array}{l}\text { Cointegration } \\
\text { confirmed }\end{array}$ & Cointegration & No cointegration \\
\hline Type of model & VECM & Type of model & VAR \\
\hline Heteroskedasticity & $\begin{array}{l}\text { Heteroskedasticity } \\
\text { confirmed }\end{array}$ & Heteroskedasticity & $\begin{array}{l}\text { Heteroskedasticity } \\
\text { confirmed }\end{array}$ \\
\hline Autocorrelation & No autocorrelation & Autocorrelation & $\begin{array}{l}\text { Autocorrelation } \\
\text { confirmed }\end{array}$ \\
\hline
\end{tabular}
\end{tabular}

Source: Authors

Figure 1: Impulse response functions
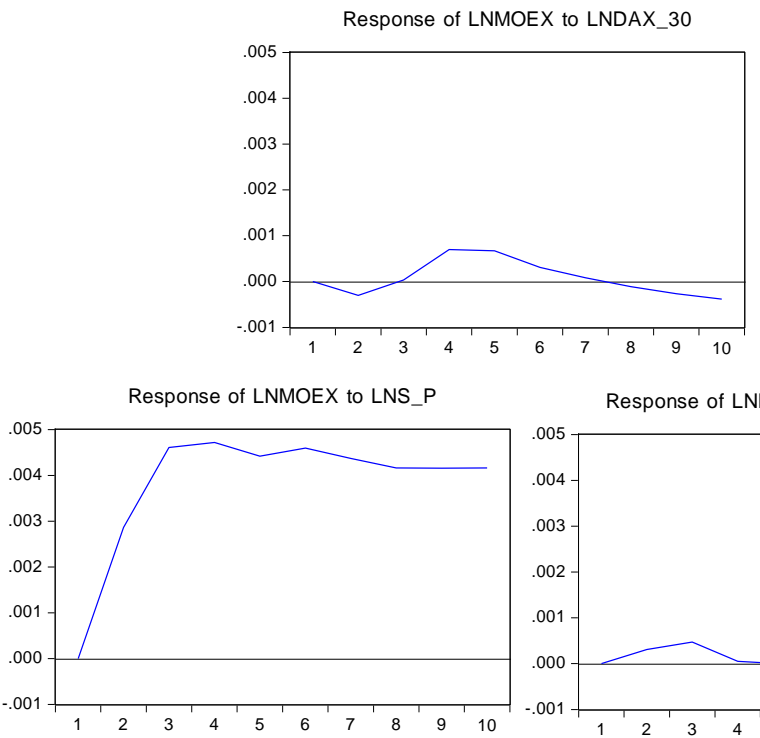

Response of LNMOEX to LNHANG_SENG



Source: Authors 
The fact that there is no autocorrelation of the first and subsequent orders speaks in favor of the first model, as well as the fact that for the 4th lag, more information criteria were preferred. Based on the results of the comparison, model 1 was selected for constructing the impulse response functions represented in Figure 1.

Based on the charts, single price impulses for S\&P500 cause a positive response from the stock market of the Russian Federation. This response does not fade over time, it remains constant. Dax30 impulses cause a weak negative response from the Russian stock market. The response ceases to be significant at the 4th lag. The opposite situation occurs for the Hang-Seng and the Moscow Exchange index pair: the Chinese stock market causes a weakly positive response from the Russian stock market.

\section{Discussion and Conclusions}

This research was aimed at determining the dependence degree of the Russian stock market on the markets of China, Germany, and the U.S. The Granger test for causality showed that there is not only long-term but also short-term interdependence between the Russian and United States stock market; the dynamics of the S\&P500 stock index strongly influence the Moscow Exchange index. As a result of checking the robustness of these models, it turned out that the model with 4 lags is the most robust. Subsequently, the model was quantified using the impulse response function. It turned out that the U.S. market has a considerable influence on the Russian market, causing a positive response.

The final model can quantitatively reflect the qualitative relationship that exists between the stock markets of the United States, Russia, and China. Determining the nature of the relationship can help in making management decisions for hedge funds, as well as for private investors.

This study has a valuable practical significance for investors from the researched countries, stock market stakeholders and policymakers. To predict changes in the Russian MOEX index, it is essential to pay attention to the major U.S. index S\&P500. The MOEX displays a similar movement as the S\&P500 with a delay. To diversify an investment portfolio that comprises MOEX stocks for hedging purposes, it is not advisable to use only the S\&P500 and the companies that compose it, while stocks of the Dax30 and Hang-Seng can be considered for inclusion.

\section{Acknowledgements}

The research was supported by the grant of the Russian Science Foundation № 19-18-00262

"Empirical modelling of balanced technological and socioeconomic development in the Russian regions".

\section{References}

Alwadi, S., Tahir Ismail, M., Khazaleh, A., Ariffin Abdul Karim, S. B., Al Wadi, S., Alkhahazaleh, M. H., \& Ariffin Addul Karim, S. (2011). Selecting Wavelet Transforms Model in Forecasting Financial Time Series Data Based on ARIMA Model In Applied Mathematical Sciences (Vol. 5, Issue 7). https://www.researchgate.net/publication/265205660

Berument, H., \& Ince, O. (2005). Effect of S\&P500's return on emerging markets: Turkish experience. Applied Financial Economics Letters, 1(1), 59-64. https://doi.org/10.1080/1744654052000314662

Demidova, O. A. (2020). Lecture in econometrics. Autocorrelation, no. 3.

https://www.hse.ru/mirror/pubs/share/358351124.pdf

Fantazzini, \& Dean. (2008). An Econometric Analysis of Financial Data in Risk Management. Applied Econometrics, 10(2), 91-137. https://ideas.repec.org/a/ris/apltrx/0006.html

Fedorova, E. A. (2013). Evaluation of the Impact of the U.S., Chinese and German Stock Markets on the Russian Stock Market. Economic Analysis: Theory and Practice, 47, 350.

Fedorova, E. A., \& Nazarova, Y. N. (2010). Identification of factors affecting the volatility of the stock market, using cointegration approach. Economic Analysis: Theory and Practice, 3.

Finam. (2020). The number of private investors on the MosExchange exceeded 7.5 million in October. Review from Finam. https://www.finam.ru/analysis/newsitem/kolichestvo-chastnyx-investorov-na-mosbirzhe-v-oktyabre-prevysilo-7-5-mlnchelovek-20201105-174629/

Kanas, A. (1998). Linkages between the US and European equity markets: Further evidence from cointegration tests. Applied Financial Economics, 8(6), 607-614. https://doi.org/10.1080/096031098332646

Karpov, K. (2017). Rating of MICEX index drivers. Analytical note of BCS. BCS Express. https://bcs-express.ru/novosti-ianalitika/reiting-draiverov-indeksa-mmvb

Khromov, E. A. (2010). Fundamental Analysis of Shares. Finance and Credit, $28,412$.

Kularatne, C. (2002). An Examination of the Impact of Financial Deepening on Long-Run Economic Growth:An Application of a VECM Structure to a Middle-Income Country Context. The South African Journal of Economics, 70(4), 300-319. https://doi.org/10.1111/j.1813-6982.2002.tb01185.x 
Lin, Z. (2018). Modelling and forecasting the stock market volatility of SSE Composite Index using GARCH models. Future Generation Computer Systems, 79, 960-972. https://doi.org/10.1016/j.future.2017.08.033

Linkova, M. V. (2016). Technical analysis: concept, essence and axioms. Territory of Science, 3.

Mukherjee, P., \& Bose, S. (2008). Does the stock market in India move with Asia? A multivariate cointegration-vector autoregression approach. Emerging Markets Finance and Trade, 44(5), 5-22. https://doi.org/10.2753/REE1540-496X440501

Pesaran, H. M., Schuermann, T., \& Smith, L. V. (2009). Forecasting economic and financial variables with global VARs. International Journal of Forecasting, 25, 642-675. https://doi.org/10.1016/j.ijforecast.2009.08.007

Samoylov, D. V. (2010). Factors Influencing the RTS Index during the Financial Crisis of 2008-2009 and before it. HSE Economic Journal, 2.

Sarwar, S., Tiwari, A. K., \& Tingqiu, C. (2020). Analyzing volatility spillovers between oil market and Asian stock markets. Resources Policy, 66(June 2019), 101608. https://doi.org/10.1016/j.resourpol.2020.101608

Shrestha, M., \& Chowdhury, K. (2005). ARDL Modelling Approach to Testing the Financial Liberalisation Hypothesis. Faculty of Business - Economics Working Papers. https://ro.uow.edu.au/commwkpapers/121

Taveeapiradeecharoen, P., Chamnongthai, K., \& Aunsri, N. (2019). Bayesian Compressed Vector Autoregression for Financial Time-Series Analysis and Forecasting. IEEE Access, 7, 16777-16786. https://doi.org/10.1109/ACCESS.2019.2895022

Taylor, S. J. (2007). Modelling Financial Time Series (2nd Edition). World Scientific Publishing Company. https://books.google.ru/books?id=xVLICgAAQBAJ

Urazbaeva, A., Voytenkov, V., \& Groznykh, R. (2020). The analysis of COVID-19 impact on the internet and telecommunications service sector through modelling the dependence of shares of Russian companies on the American stock market. R-Economy, 6(3), 162-170. https://doi.org/10.15826/recon.2020.6.3.014

Xiao, L., \& Dhesi, G. (2010). Dynamic linkages between the European and US stock markets. Proceedings - 3rd International Conference on Business Intelligence and Financial Engineering, BIFE 2010, 403-407. https://doi.org/10.1109/BIFE.2010.99

Zeltser, M. (2020). A study of the relationship between the U.S. and Russian stock markets. Analytical note of BCS. BCS Express. 